\title{
Interleukin-8 Expression by Fetal and Neonatal Pulmonary Cells in Hyaline Membrane Disease and Amniotic Infection
}

\author{
ANITA GÄHLER, THOMAS STALLMACH, JÜRG SCHWALLER, MARTIN F. FEY, AND \\ ANDREAS TOBLER \\ Department of Clinical Research [A.G., J.S., M.F.F, A.T.], the Central Hematology Laboratory [A.T.], the \\ Institute of Medical Oncology [M.F.F.], University of Berne, CH-3010 Berne, Switzerland, and the Institut \\ of Clinical Pathology, University Hospital Zürich [T.S.], CH-8091 Zürich, Switzerland
}

\section{ABSTRACT}

\begin{abstract}
IL-8, a chemokine with striking neutrophil-activating properties, is important in the pathogenesis of various disorders of the adult lung. Little is known about its production and possible role in fetal and neonatal lung disorders. We therefore examined IL-8 expression by immunohistochemistry in lung tissue from neonates with hyaline membrane disease, from fetuses with amniotic infection, and from a fetal control group with noninflammatory diseases. In the majority of cases with hyaline membrane disease, intense IL-8 immunoreaction was seen in fetal and neonatal neutrophils and in almost half of these cases, in epithelial cells of the terminal airways as well as in the connective tissue cell compartment. In contrast, in the amniotic infection group, strong IL-8 immunostaining was almost exclusively seen in maternal aspirated neutrophils. Little or no IL-8 signal was seen in the control cases in all cell types examined. Also, no IL-8 production by fetal lung cells was detected in fetuses $<18$ wk of gestation.
\end{abstract}

The marked presence of IL- 8 in all cell types of the lung in hyaline membrane disease cases indicates a role for IL- 8 in the pathobiology of hyaline membrane disease possibly similar to that in adult respiratory distress syndrome. It further suggests that the cytokine network of the fetal lung is already well developed by the second trimester of pregnancy. (Pediatr Res 48: 299-303, 2000)

Abbreviations
HMD, hyaline membrane disease
ARDS, adult respiratory distress syndrome
TNF- $\alpha$, tumor necrosis factor- $\alpha$
RDS, respiratory distress syndrome
LPS, lipopolysaccharide
BAL, bronchoalveolar lavage

IL-8 belongs to a family of structurally related proinflammatory cytokines designated as C-X-C-chemokines (1-3). It is produced by an array of normal cells, including monocytes (4), neutrophils (5), and cells of the human placenta (6). In the lung, alveolar macrophages (7), epithelial cells (8), fibroblasts (9), microvascular endothelium (10), and smooth muscle cells in arterial walls (11) are sources of IL-8.

During pregnancy, IL-8 is constitutively produced by human placenta, and its expression is enhanced in intrauterine infections (6). In various pulmonary disorders of children and adults, IL-8 seems to be critical for direct recruitment of neutrophils, for example, in $\operatorname{ARDS}(12,13)$, asthma (14), idiopathic pulmonary fibrosis (15), and bacterial pneumonia (16). The migration of leukocytes to the pulmonary interstitium or air space in inflammatory processes is dependent on several

\footnotetext{
Received August 5, 1999; accepted March 5, 2000.

Correspondence: A. Tobler, M.D., Central Hematology Laboratory, University Hospital/Inselspital Bern, CH-3010 Bern, Switzerland.

Supported in part by a grant from the Swiss National Science Foundation.
}

cytokine mediators, including TNF- $\alpha$, IL-1, and chemokines $(1,17)$. In lung tissue, IL-8 appears to be the major neutrophil chemotactic factor (18). The rapid and marked production of IL-8 is part of a cascade-like interaction between various cells of the alveolar-capillary wall. Alveolar macrophages can respond in vitro to initial stimuli (LPS, bacteria, immune complexes) by producing different proinflammatory cytokines such as IL-1, TNF- $\alpha$, and IL-8 $(7,17)$. IL- 1 and TNF- $\alpha$ then induce the release of additional IL- 8 by alveolar macrophages, type II pneumocytes, fibroblasts, and endothelial cells. This cascade might lead to the brisk accumulation of IL- 8 followed by the migration of neutrophils to the pulmonary interstitium or air spaces (17). In addition, neutrophils produce IL-8 in response to a variety of inflammatory stimuli, such as LPS, IL-1, and TNF- $\alpha$, which suggests that neutrophils amplify their own recruitment in an autocrine loop (5). Neutrophils also produce IL-1 and TNF- $\alpha$ (19) and may thus in turn enhance the production of IL- 8 by pulmonary epithelial and stromal cells.

Several previous reports suggest a key role for IL-8 in inflammatory reactions of fetuses and newborns. In vitro, fetal 
mononuclear cells produce IL-8 in response to LPS in chorioamnionitis (20), and neonatal pulmonary fibroblasts have been identified as a source of IL-8 (21). In in vivo cell cultures of BAL, exogenous anti-IL-1 $\beta$ antibody resulted in a marked inhibition of IL-8 production by lung inflammatory cells (22). In vivo, increased levels of IL-8 were found in BAL obtained from premature infants with chronic lung diseases (23). Furthermore, abundant expression of IL-8 mRNA in BAL was seen in newborns who either recovered from RDS or developed chronic lung disease (24).

To gain more insights into the role of IL-8 in fetal and neonatal pulmonary disorders, we have investigated the expression of IL-8 by immunohistochemical staining of postmortem lung specimens from newborns with HMD, fetuses with amniotic infections, and fetuses with noninflammatory conditions leading to premature delivery or termination of pregnancy.

\section{METHODS}

Tissue specimens. Lung tissue specimens obtained at autopsy of 72 fetuses and neonates were classified into three groups: HMD, amniotic infections, and controls. The postmortem examination was performed within a range of 4 to $120 \mathrm{~h}$ (mean, $32 \mathrm{~h}$ ). The mean time interval between death and autopsy was not different among the three groups. The HMD group was defined by HMD, gestational age $>25 \mathrm{wk}$, and postnatal survival. The amniotic infection group was defined by amniotic infection, gestational age $\leq 25 \mathrm{wk}$, and no postnatal survival. Amniotic infection, which usually occurs after premature rupture of membranes, was diagnosed by histologic examination of the placenta. The control group included lung tissue specimens from fetuses without amniotic infection or inflammatory conditions who had died or where pregnancy had been terminated (e.g. because of dysmorphic syndromes or chromosomal abnormalities). In this group, the gestational age was $\leq 25 \mathrm{wk}$. No age-matched controls are available for the HMD because at that age almost all infants die with signs of lung pathology.

Antibodies and reagents. Monoclonal mouse anti-human IL-8 antibody (clone 6217.11, IgG, neutralizing) was from R\&D Systems Europe Ltd. (Abingdon, UK). The primary antibody was chosen after testing several antibodies for crossreactions against other $\mathrm{CXC} / \mathrm{CC}$-chemokines (ELISA); no cross-reactions were detected (results not shown). Bridging antibody and alkaline phosphatase anti-alkaline phosphatase complexes (APAAP) complexes were from DAKO (Glostrup, Denmark). The antibody was tested for its reactivity for IL-8 on cytospin preparations of HL-60 cells known to produce IL-8 protein (25). Jurkat cells, which do not produce IL-8 (25), were used as negative control. Human recombinant IL-8 was from Sandoz AG (Vienna, Austria).

Immunohistochemical staining. Tissue specimens were fixed in $4 \%$ buffered formalin for $24 \mathrm{~h}$ and embedded in paraffin. Tissue sections $(5 \mu \mathrm{m})$ were prepared on poly-Llysine-treated slides, deparaffined with xylene, and rehydrated through isopropanol and graded concentrations of ethanol. For antigen unmasking, the slides were treated with microwave heat in $0.01 \mathrm{M}$ citrate buffer for $10 \mathrm{~min}$ at medium power (26). Immunostaining was performed according to the APAAP method (27). Briefly, the slides were incubated with the MAb $[\sim 20 \mu \mathrm{g} / \mathrm{mL}$ in $0.05 \mathrm{M}$ Tris-buffered saline (TBS) $/ 0.5 \%$ bovine serum albumin] for $2 \mathrm{~h}$, followed by a rabbit anti-mouse antibody (Z-259; DAKO) and the APAAP-complex (D-651; DAKO). After each incubation step, the slides were vigorously washed in TBS. To enhance the signal, incubation with the second antibody and the APAAP complexes were repeated once. The slides were developed with a mixture of naphthol AS-MX sodium salt, Fast Red TR, and levamisole (Sigma Chemical Co., St. Louis, MO, U.S.A.), all in veronal acetate buffer. After counterstaining with Mayer's hematoxylin, the slides were cover-slipped using an aqueous mounting medium. No specific signals were seen when the first antibody was omitted or by incubation with mouse control serum (Ig $\mathrm{G}_{1}$, $\mathrm{X}-931$; DAKO). As an additional control experiment, preabsorption with recombinant human IL-8 was performed, which inhibited IL-8-specific staining.

For immunohistochemical analysis of IL-8 production, tissue sections were divided into five cellular compartments: epithelium of bronchioli, epithelium of alveoli, fetal and neonatal neutrophils, maternal aspirated neutrophils, and connective tissue. These cells were defined morphologically. Cells exhibiting an intense signal were considered as IL-8 positive, and cells with no or very weak staining as negative for IL-8. The percentage of IL-8-positive bronchial and alveolar epithelial cells was assessed by counting 500 cells; the percentage of IL-8 expression in aspirated maternal neutrophils and neonatal and fetal neutrophils was determined by examining 100 cells. Maternal and fetal neutrophils were distinguished by morphology. Fetal neutrophilic granulocytes are predominantly located within the vasculature of the lungs, and their nuclei are oval or indented. In contrast, maternal neutrophils are seen within alveolar spaces and they display highly segmented nuclei. The specimens were classified into three groups according to the percentage of IL-8-positive cells: 51 to $100 \%$ positive cells (denoted as ++ in Table 1); 11 to $50 \%$ positive cells (denoted as + ); and 0 to $10 \%$ positive cells (denoted as - ).

\section{RESULTS}

Patients' characteristics and diagnostic groups are shown in Table 2. Of the 72 fetal and neonatal autopsy lung specimens studied, 22 were classified as HMD, 30 as amniotic infection, and 20 were in the control group. The mean gestational age in the HMD group was $28.3 \mathrm{wk}$ (range, 26 to $40 \mathrm{wk}$ ) as calculated from the first day of the last menstruation, and the mean postpartal survival was $2.2 \mathrm{~d}$ (range, 0.01 to $9 \mathrm{~d}$ ). In the amniotic group, mean gestational age was $20.3 \mathrm{wk}$ (range, 13 to $25 \mathrm{wk}$ ), and in the control group, the mean gestational age was $20.1 \mathrm{wk}$ (range, 17 to $24 \mathrm{wk}$ ).

All lung specimens from fetuses with IL-8 immunopositive fetal cells had a gestational age $>18$ wk. Six patients of the amniotic infection group had a gestational age $<18 \mathrm{wk}$, and the youngest fetus examined had a gestational age of $13 \mathrm{wk}$.

In HMD, IL-8 protein was seen within neonatal cells in 17 of the 22 patients examined (Table 1). Five specimens were 
Table 1. Expression of IL-8 by different cells in 72 fetal and neonatal lung autopsy specimens

\begin{tabular}{|c|c|c|c|}
\hline \multicolumn{2}{|c|}{ Diagnosis } & $\begin{array}{l}\text { Epithelium of } \\
\text { bronchioli }\end{array}$ & $\begin{array}{r}\text { Epith } \\
\text { al }\end{array}$ \\
\hline \multicolumn{2}{|c|}{$\operatorname{HMD}(n=22)$} & $9(4+/ 5++)$ & $5(0+$ \\
\hline \multicolumn{2}{|c|}{$\mathrm{AI}(n=30)$} & $2(1+/ 1++)$ & $2(2+$ \\
\hline \multicolumn{2}{|c|}{ Controls $(n=20)$} & $2(2+/ 0++)$ & All ca \\
\hline \multirow{2}{*}{\multicolumn{4}{|c|}{$\begin{array}{l}\text { Abbreviation: AI: amniotic infection. } \\
(++) \text { specimens with }>50 \% \text { IL- } 8 \text {-positive cells. } \\
(+) \text { specimens with } 11-50 \% \text { IL- } 8 \text {-positive cells. } \\
\text { (-) specimens with } 0-10 \% \text { IL- } 8 \text {-positive cells, which were considered as } \\
\text { Table 2. Characteristics of patients }(n=72) \text { : gestional age and } \\
\text { diagnostic groups }\end{array}$}} \\
\hline & & & \\
\hline $\begin{array}{l}\text { Gestational age } \\
\text { (wk) }\end{array}$ & $\begin{array}{c}\text { HMD } \\
(n=22)\end{array}$ & $\begin{array}{l}\text { Amniotic infection } \\
\text { (AI) }(n=30)\end{array}$ & $\begin{array}{l}\text { Controls } \\
(n=20)\end{array}$ \\
\hline 13 & - & 1 & - \\
\hline $14-16$ & - & 2 & - \\
\hline $17-19$ & - & 10 & 8 \\
\hline $20-22$ & - & 6 & 9 \\
\hline $23-25$ & - & 11 & 3 \\
\hline $26-28$ & 16 & - & - \\
\hline $29-31$ & 3 & - & - \\
\hline $32-34$ & 1 & - & - \\
\hline $35-37$ & 1 & - & - \\
\hline $38-40$ & 1 & - & - \\
\hline $\begin{array}{r}\text { Mean age } \\
\text { (range) }\end{array}$ & $28.3(26-40)$ & $20.3(13-25)$ & $20.1(17-24)$ \\
\hline
\end{tabular}

negative for neonatal IL-8 expression. All 17 positive specimens showed marked IL-8 protein staining in neonatal neutrophils. In nine of these specimens, IL-8 expression was also noted in bronchial epithelial cells, and in five of those, both bronchial and alveolar epithelial were positive für IL-8. The latter five infants also showed IL-8 positivity in adjacent connective tissue cells, such as endothelial cells, fibroblasts, and smooth muscle cells of vessels as well as chondrocytes (Fig. 1, $A$ and $B$ ).

The HMD specimens were also analyzed with regard to the presence of bacteria, pneumonia, and amniotic infection. Interestingly, bacteria were found only in the five specimens with marked IL-8 protein expression in all tissue compartments. Two of these infants also had pneumonia. No bacteria were found in the remaining patients. Signs of pneumonia were also found in three other specimens, which were positive for IL-8 in bronchial epithelial cells but negative in alveolar cells. Only five of 22 infants showed concomitant amniotic infection. In these patients, no association was seen between amniotic infection and IL-8 immunoreactivity.

The mothers of nine of the 22 HMD patients received cortisone treatment for induction of fetal lung maturation. No association was seen between levels of IL-8 protein and steroid therapy.

In contrast to HMD, only two of 30 specimens of the amniotic infection group showed IL-8 immunoreactivity in the epithelium of alveoli and bronchioli and in a few scattered connective tissue cells. However, in 23 of the 30 specimens, a strong IL-8 immunostaining was seen in up to $100 \%$ of abun-
Cellular compartments

Number of cases with IL-8 positive cells)*

\begin{tabular}{ccc}
$\begin{array}{c}\text { pithelium of } \\
\text { alveoli }\end{array}$ & Neutrophils & Neutrophils \\
\hline$(0+/ 5++)$ & $17(4+/ 13++)$ & $3(0+/ 3++)$ \\
$(2+/ 0++)$ & $10(0+/ 10++)$ & $23(0+/ 23++)$ \\
All cases $(-)$ & $2(0+/ 2++)$ & All cases $(-)$
\end{tabular}

Maternal cells

-8 negative.

dantly present maternal neutrophils, which were located in alveoli and bronchioli (Fig. 1C). In a third of all specimens with amniotic infection, not only the aspirated maternal neutrophils but also the fetal neutrophils were positive for IL-8. No association between levels of IL-8 expression and factors for amniotic infection (e.g. increased granulopoiesis in the liver, occurrence of bronchus-associated lymphatic tissue in the lungs, maternal leukocyte count, C-reactive protein, time interval between premature rupture of membranes and birth) or treatment of mothers with steroids was found.

In the control group, notable IL-8 production was found only in two of 20 specimens in neutrophils, in epithelial cells of bronchioli but not of alveoli, and in connective tissue cells (Fig. 1D). No maternal neutrophils were seen.

\section{DISCUSSION}

We examined IL-8 production by immunohistochemical staining in normal and pathologic fetal and neonatal lung tissue. In patients with HMD and amniotic infections, IL-8 expression was observed in all cell types of the lung (epithelial cells, fetal, neonatal, and maternal neutrophils, connective tissue), although to various degrees and in different patterns. In contrast, no IL-8 signal was seen in the great majority of the control specimens.

Deficiency or dysfunction of surfactant leads to alveolar collapse, hypoxia, and acute lung injury, with severe epithelial and endothelial lesions in HMD of premature neonates as well as in ARDS (28). ARDS and HMD also show similar pathologic features, with damage of the alveolar-capillary wall, development of hyaline membranes, and alveolar collapse. This implies similar pathogenic mechanisms for the formation of hyaline membranes in adults and neonates (29). The role of IL-8 in ARDS is well established. Elevated IL-8 levels were found in bronchioalveolar fluid from ARDS patients (13); moreover, high IL-8 levels were associated with a poor prognosis in ARDS (12). Similarly, increased IL-8 production was detected in alveolar macrophages, neutrophils, and exfoliated epithelial cells in BAL from neonates suffering from RDS (24). Our findings of strong IL-8 immunostaining in all neonatal lung cell compartments in nine of 22 patients with severe HMD confirm and extend these previous studies by demonstrating that in cases with extensive HMD, not only inflammatory cells in the air spaces but also epithelial cells of the terminal 


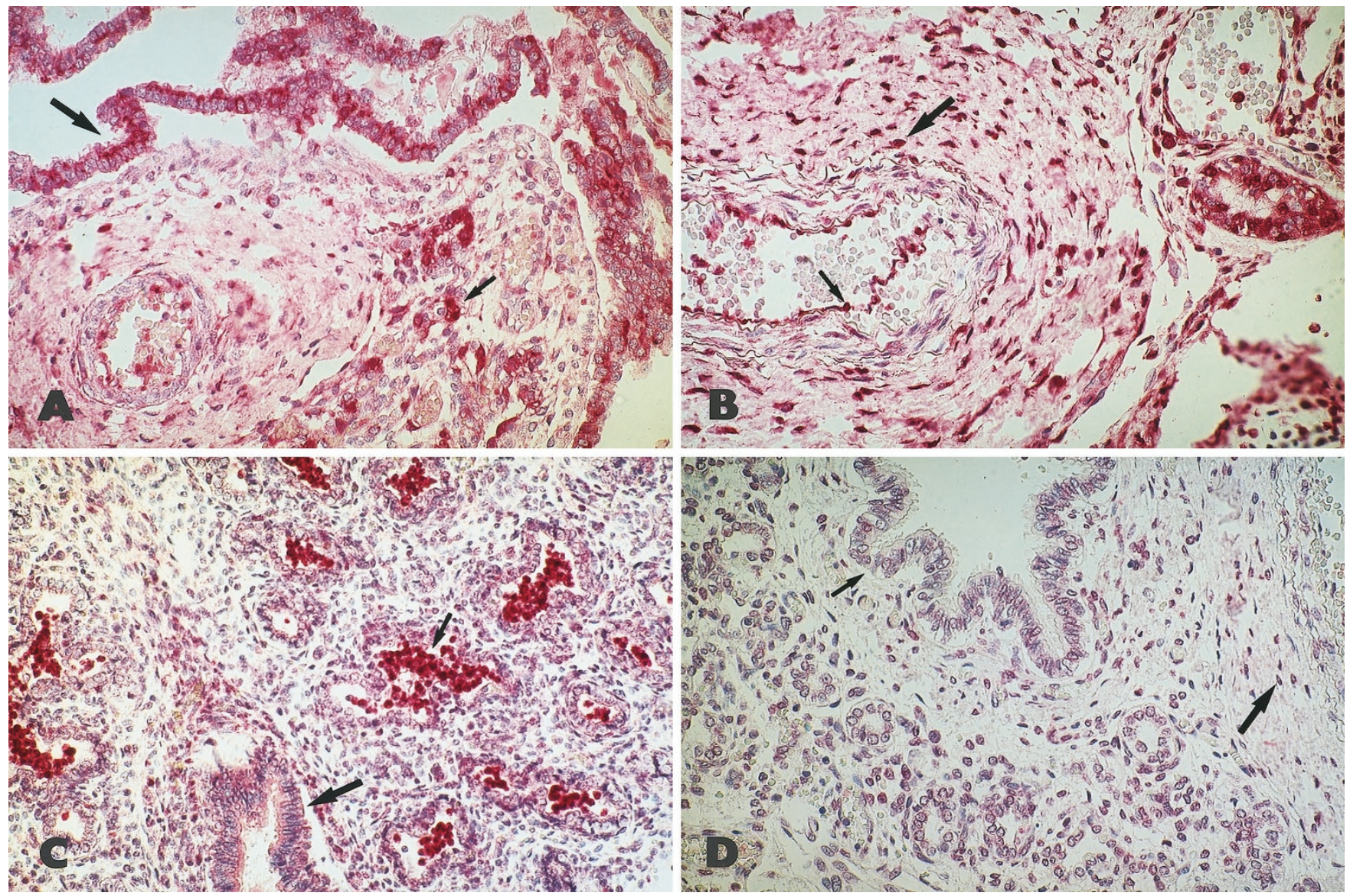

Figure 1. $A$, IL-8 protein in a neonatal lung with HMD (29 wk of gestational age). IL-8-positive alveolar cells $(\rightarrow)$ and immunoreactive bronchial cells $(\mathbf{\Delta})$ are seen in the area of epithelial ulcerations (anti-IL-8, APAAP; $\times 200)$. B, IL-8 protein in a neonatal lung with HMD (27 wk of gestational age). Intense IL-8 signal is seen in the endothelium $(\rightarrow)$ and smooth muscle cells of the vessels $(\mathbf{\Delta}$; anti-IL-8, APAAP; $\times 200)$. $C$, IL-8 protein in a fetal lung with aspiration of maternal neutrophils during amniotic infection (19 wk of gestational age). Numerous IL-8-positive aspirated neutrophils $(\rightarrow)$ are present, whereas the epithelial cells of the bronchioli and alveoli $(\mathbf{\Delta})$ are negative (anti-IL-8, APAAP, $\times 200$ ). D, IL-8 protein expression in a fetal lung from the control group (22 wk of gestational age). Epithelium of the bronchioli $(\rightarrow)$ and the alveoli as well as cells of the connective tissue $(\mathbf{\Lambda})$ are IL-8 negative (anti-IL-8, APAAP; $\times 200)$.

airways, as well as connective tissue cells, produce IL-8. Bacteria were found in blood vessels or in tissue in five of the 22 children of the HMD group. Interestingly, these five infants showed the strongest IL-8 expression in all tissue compartments examined. These findings suggest that IL-8 might play an important role in HMD, in particular in neonates suffering from RDS associated with sepsis. Also, in HMD associated with pneumonia, IL-8 positivity was not restricted to the areas with pneumonia, which indicates that neighboring tissue may also be damaged by increased IL-8 production.

In five patients with HMD, immunoreactivity for IL-8 was weak or absent in all cell types. This might be explained by the limited sensitivity of the method used, sampling errors, or limited postpartal survival. Our finding of widespread IL-8 production in all cellular compartments in neonatal lungs with severe HMD nevertheless suggests that IL-8 production might be part of a cascade-like interaction between different cells of the neonatal lung similar to the cytokine network operating in the adult lung. Early expression of the C-C chemokine macrophage inflammatory protein- $1 \alpha$ was found to be associated with later development of fibrosis and a poor outcome in RDS (30). Our study implies that IL-8 might be one important factor in the development of HMD, and in agreement with previous reports $(30,31)$, our study confirms an inflammatory response in neonatal RDS beginning within the first day of life.

Amniotic infections often lead to inflammation of the fetal lung by aspiration of bacteria-containing amniotic fluid. Detection of neutrophils in aspirated material represents an early stage of fetal lung infection (32). In contrast to HMD, in fetuses with amniotic infection, strong IL-8 immunoreactivity was mostly confined to maternal aspirated neutrophils as well as fetal neutrophils. This finding is consistent with previous reports, which demonstrated high levels for IL-8, IL-1, and TNF- $\alpha$ in amniotic fluid from fetuses with amniotic infection $(6,33,34)$. One might perhaps have expected an induction of IL-8 in fetal pulmonary epithelial and connective tissue cells. The near absence of IL- 8 positivity in these cell types in our patients with amniotic infection may primarily be explained by their early gestational age. Indeed, fetuses with amniotic infection and a gestational age of $\geq 18$ wk revealed IL- 8 expression in their granulocytes. This is in agreement with the finding that mRNA for other proinflammatory cytokines, such as IL-1 and TNF- $\alpha$, has been detected in fetuses $>20$ wk of gestation, suggesting maturity of the fetal cytokine response by the second trimester of pregnancy (35). 
High IL-8 production in all cellular compartments of the neonatal lung in cases with HMD suggests that IL-8 might contribute to the development of HMD. In contrast, in amniotic infections the fetal lung seems to be mostly affected by maternal IL-8-releasing neutrophils.

We thank Prof. E. Bossi, Childrens Department, University Hospital/Inselspital Bern, for his helpful comments and suggestions.

\section{REFERENCES}

1. Baggiolini M, Dewald B, Moser B 1994 Interleukin-8 and related chemotactic cytokines: CXC and CC chemokines. Adv Immunol 55:97-179

2. Luster AD 1998 Chemokines: chemotactic cytokines that mediate inflammation. N Engl J Med 338:436-445

3. Kunkel SL, Lukacs N, Strieter RM 1995 Chemokines and their role in human disease. Agents Actions Suppl 46:11-22

4. Yoshimura T, Matsushima K, Oppenheim JJ, Leonard EJ 1987 Neutrophil chemotactic factor produced by lipopolysaccharide stimulated human blood mononuclear leukocytes: partial characterization and separation from interleukin-1. J Immunol 139:788-793

5. Strieter RM, Kasahara K, Allen RM, Standiford TJ, Rolfe MW, Becker FS, Chensue SW, Kunkel SL 1992 Cytokine-induced neutrophil-derived interleukin-8. Am J Pathol 141:397-407

6. Shimoya K, Matsuzaki N, Taniguchi T, Kameda T, Koyama M, Neki R, Saji F, Tanizawa O 1992 Human placenta constitutively produces interleukin-8 during pregnancy and enhances its production in intrauterine infection. Biol Reprod 47:220226

7. Strieter RM, Chensue SW, Basha MA, Standiford TJ, Lynch III JP, Baggiolini M, Kunkel SL 1990 Human alveolar macrophage gene expression of interleukin- 8 by tumor necrosis factor- $\alpha$, lipopolysaccharide, and interleukin-1 $\beta$. Am J Respir Cell Mol Biol 2:321-326

8. Standiford TJ, Kunkel SL, Basha MA, Chensue SW, Lynch III JP, Toews GB, Westwick J, Strieter RM 1990 Interleukin-8 gene expression by a pulmonary epithelial cell line. J Clin Invest 86:1945-1953

9. Rolfe MW, Kunkel SL, Standiford TJ, Chensue SW, Allen RM, Evanoff HL, Phan SH, Strieter RM 1991 Pulmonary fibroblast expression of interleukin-8: a model for alveolar macrophage-derived cytokine networking. Am J Respir Cell Mol Biol 5:493-501

10. Brown Z, Gerritsen ME, Carley WW, Strieter RM, Kunkel SL, Westwick J 1994 Chemokine gene expression and secretion by cytokine-activated human microvascular endothelial cells. Am J Pathol 145:913-921

11. Lukacs NW, Kunkel SL, Allen R, Evanoff HL, Shaklee CL, Sherman JS, Burdick MD, Strieter RM 1995 Stimulus and cell-specific expression of CXC and CC chemokines by pulmonary stromal cell populations. Am J Physiol 268:L856-L861

12. Donnelly SC, Strieter RM, Kunkel SL, Walz A, Robertson CR, Carter DC, Grant IS, Pollok AJ, Haslet C 1993 Interleukin-8 and development of adult respiratory distress syndrome in at-risk patient groups. Lancet 341:643-647

13. Miller EJ, Cohen AB, Nagao S, Griffith D, Maunder RJ, Martin TR, Weiner-Kronish JP, Sticherling M, Christophers E, Matthay MA 1992 Elevated levels of NAP-1/ interleukin- 8 are present in the airspaces of patients with the adult respiratory distress syndrome and are associated with increased mortality. Am Rev Respir Dis 146:427432

14. Marini M, Vittori E, Hollemborg J, Mattoli S 1992 Expression of the potent inflammatory cytokines, granulocyte-macrophage-colony-stimulating factor and interleukin-6 and interleukin-8, in bronchial epithelial cells of patients with asthma. J Allergy Clin Immunol 89:1001-1009
15. Lynch III JP, Standiford TJ, Rolfe MW, Kunkel SL, Strieter RM 1992 Neutrophilic alveolitis in idiopathic pulmonary fibrosis: the role of interleukin-8. Am Rev Respir Dis 145:1433-1439

16. Standiford TJ, Kunkel SL, Greenberger MJ, Laichalk LL, Strieter RM 1996 Expression and regulation of chemokines in bacterial pneumonia. J Leukocyte Biol 59:24-28

17. Strieter RM, Kunkel SL 1994 Acute lung injury: the role of cytokines in the elicitation of neutrophils. J Invest Med 42:640-651

18. Kunkel SL, Standiford T, Kasahara K, Strieter RM 1991 Interleukin-8: the major neutrophil chemotactic factor in the lung. Exp Lung Res 17:17-23

19. Strieter RM, Kasahara K, Allen RM, Showell HJ, Standiford TJ, Kunkel SL 1990 Human neutrophils exhibit disparate chemotactic factor gene expression. Biochem Biophys Res Commun 173:725-730

20. Taniguchi T, Matsuzaki N, Shimoya K, Neki R, Okada T, Kitajima H, Saji F, Tanizawa O 1993 Fetal mononuclear cells show a comparable capacity with maternal mononuclear cells to produce IL-8 in response to lipopolysaccharide in chorioamnionitis. J Reprod Immunol 23:1-12

21. Stancombe BB, Walsh WF, Derdak S, Dixon P, Hensley D 1993 Induction of human neonatal pulmonary fibroblast cytokines by hyperoxia and Ureaplasma urealyticum. Clin Infect Dis 17(suppl 1):S154-S157

22. Kwong KY, Jones CA, Cayabyab R, Lecart C, Stotts CL, Randhawa I, Ramanathan R, Khuu N, Minoo P, deLemos RA 1998 Differential regulation of IL-8 by IL-1beta and TNF alpha in hyaline membrane disease. J Clin Immunol 18:71-80

23. McColm JR, McIntosh N 1994 Interleukin-8 in bronchoalveolar lavage samples as predictor of chronic lung disease in premature infants. Lancet 343:729-729

24. Kotecha S, Wilson L, Wangoo A, Silverman M, Shaw RJ 1996 Increase in interleukin- $1 \beta$ and interleukin- 6 in bronchoalveolar lavage fluid obtained from infants with chronic lung disease of prematurity. Pediatr Res 40:250-256

25. Tobler A, Moser B, Dewald B, Geiser T, Studer H, Baggiolini M, Fey MF 1993 Constitutive expression of interleukin- 8 and its receptor in human myeloid and lymphoid leukemia. Blood 82:2517-2525

26. Cattoretti G, Pileri S, Parravicini C, Becker MHG, Poggi S, Bifulco C, Key G, D'Amato L, Sabattini E, Feudale E, Reynolds F, Gerdes J, Rilke F 1993 Antigen unmasking on formalin-fixed, paraffin-embedded tissue sections. J Pathol 171:83-98

27. Cordell JL, Falini B, Erber WN, Ghosh AK, Abdulaziz Z, Macdonald S, Pulford KAF, Stein H, Mason DY 1984 Immunoenzymatic labeling of monoclonal antibodies using immune complexes of alkaline phosphatase and monoclonal anti-alkaline phosphatase (APAAP complexes). J Histochem Cytochem 32:219-229

28. Whitsett JA 1991 Pulmonary surfactant and respiratory distress syndrome in the premature infant. In: Crystal RG, West JB (eds) The Lung. Raven Press, New York, pp $1723-1733$

29. Speer PC, Ruess D, Harms K Herting E, Gefeller O 1993 Neutrophil elastase and acute pulmonary damage in neonates severe respiratory distress syndrome. Pediatrics 91:794-799

30. Murch SH, Costeloe K, Klein NJ, MacDonald TT 1996 Early production of macrophage inflammatory protein- $1 \alpha$ occurs in respiratory distress syndrome and is associated with poor outcome. Pediatr Res 40:490-497

31. Murch SH, Costeloe K, Klein NJ, Rees H, McIntosh N, Keeling JW, MacDonald TT Mucosal tumor necrosis factor- $\alpha$ production and extensive disruption of sulfated glycosaminoglycans begin within hours of birth in neonatal respiratory distress syndrome. Pediatr Res 40:484-489

32. Nakamura Y 1993 Pulmonary disorders in infants. Acta Pathol Jpn 43:347-359

33. Romero R, Ceska M, Avila C, Mazor M, Behnke E, Lindley I 1991 Neutrophil attractant/activating peptide-1/interleukin- 8 in term and preterm parturition. Am J Obstet Gynecol 165:813-820

34. Stallmach T, Hebisch G, Joller H, Koldith P, Engelmann M 1995 Expression pattern of cytokines in the different compartments of the feto-maternal unit under various conditions. Reprod Fertil Dev 7:1573-1580

35. Jarvis JN, Deng L, Berry SM, Romero R, Moore H 1995 Fetal cytokine expression in utero detected by reverse transcriptase polymerase chain reaction. Pediatr Res $37: 450-454$ 